\title{
Přehledová studie výzkumů předškolního vzdělávání v České republice v letech 2011-2020
}

\section{Zora Syslová, Veronika Najvarová}

\begin{abstract}
Abstrakt: Studie prinásí prehled témat a empirických poznatkù z výzkumů provedených $v$ oblasti predškolniho vzdèláváni v České republice v letech 2011-2020. Navazuje na prehledovou studii výzkumů predškolního vzdèláváni v letech 2000-2010. Studie vycházi z analýzy výzkumných stati, které byly ve sledovaném obdobi publikovány v odborných časopisech a relevantnich sbornicích. Přdkládaná studie odpovidá na výzkumné otázky: (1) Jaká témata byla ve výzkumech résena a jaké cíle byly sledovány? (2) Jaké metody byly využivány a na jakých souborech byly studie realizovány? (3) Jaká podstatná zjištèni a závèry z tèchto studii vyplynuly? $\mathrm{Na}$ základè analýzy těchto studii dospěly autorky ke zjištèním, že během sledovaného obdobi byl presunut publikačni dioraz do odborných časopisü, nicménè nedošlo k výrazné zmènè v oblasti zpracovávaných témat. V oblasti metodologie provedených výzkumů je možné sledovat posun ke kvalitativni až smišené metodologii.
\end{abstract}

Kličová slova: predškolní vzdèlávání, prehledová studie, pedagogický výzkum

\section{ÚvoD}

Monitorování a výzkum sehrávají klíčovou roli při vysvětlování úspěšnosti či neefektivnosti vzdělávacích programů, využívají se pro podporu zlepšení kvality, pomáhají analyzovat a určovat její důležité indikátory. Stávají se vlivným nástrojem pro politická rozhodnutí a při stanovování priorit důležitých pro investice do oblasti vzdělávání. Mají vliv také pro praxi, nebot́ mohou přispět $\mathrm{k}$ zavedení efektivnějších pedagogických postupů (Syslová, Borkovcová \& Průcha, 2013, s. 132).
Sběr údajů, výzkum a monitorování předškolního vzdělávání se staly jednou z pěti klíčových oblastí, které mohou účinně podpořit kvalitu předškolního vzdělávání a rané péče (OECD, 2012). Byla to také jedna ze strategických linií tzv. Bílé knihy (MŠMT, 2001), která se stala východiskem pro zpracování první přehledové studie výzkumů předškolního vzdělávání v České republice (Syslová \& Najvarová, 2012). Jejím cílem bylo přinést odpovědi na otázky: (a) jakými tématy se pedagogický výzkum zabýval v letech 2000-2010 v oblasti 
předškolního vzdělávání a (b) jaké konkrétní poznatky o předškolním vzdělávání výzkum přinesl. Výsledky ukázaly, že se výzkumy ve sledovaném období realizovaly velmi nesystematicky a neposkytovaly informace o implementaci nového Rámcového vzdélávacího programu pro predškolni vzděláváni (MŠMT, 2004). Současně také neposkytovaly validní a relevantní zjištění důležitá pro následná politická rozhodnutí o dalším směřování předškolního vzdělávání. Absence systematického monitorování vzdělávání se týkala celého vzdělávacího systému ČR a mnozí odborníci upozorňovali na to, že jen cílený a systematický monitoring systému a kvalitní pedagogický výzkum „umožňují formulovat opatření vzdělávací politiky na základě poznatků, a nikoliv na základě přesvědčení jednotlivců nebo skupin či dokonce z osobních či skupinových zájmü“ (Straková et al., 2009, s. 29).

Předškolní vzdělávání je považováno za neoddiskutovatelnou součást vzdělávacího systému ve všech vyspělých zemích světa. Podle mezinárodních výzkumů pomáhá účast dětí $\mathrm{v}$ předškolním vzdělávání vytvořit základy pro celoživotní učení a snižuje nerovnosti ve výsledcích vzdělávání (např. Sylva et al., 2004; Sammons et al., 2007; Yoshikawa et al., 2013). Kvalitní vzdělávání a péče $\mathrm{v}$ raném dětství představuje jeden z mála účinných způsobů, jak zlepšit sociální a ekonomické vyhlídky celé společnosti (Heckman, 2006; McClelland, Acock \& Morri- son, 2006). Bylo uskutečněno několik výzkumů, které ukázaly, že investice do raného vzdělávání, pokud je realizováno kvalitně, mají vysokou návratnost pro dítě samotné i pro celou společnost (Barnett, 2008; Heckman, 2011).

Přínosné je, pokud „systémy hodnocení a monitorování jsou navrženy tak, aby dosáhly, udržovaly nebo rozvíjely poskytování vysoce kvalitních služeb v oblasti předškolního vzdělávání a péče identifikováním silných a slabých stránek, na nichž lze následně stavět nebo je napravit" (European Commission, 2019, s. 121). Př́ḱladem dobré praxe by se mohly stát především výzkumy ve Spojených státech amerických, zejména longitudinální studie, které sledují dopady raného vzdělávání na pozdější vývoj a výsledky dětí. Také dobře stanovený výzkumný design přináší užitečné informace ke zlepšení vzdělávacích programů, procesů i výsledků vzdělávání dětí předškolního věku (Syslová et al., 2013, s. 132).

Výše uvedené poznatky přivedly autorky této přehledové studie $\mathrm{k}$ rozhodnutí provést tzv. literární přehled (Mareš, 2013, s. 430) výzkumů zabývajících se předškolním vzděláváním v České republice. Výsledky studie by měly přispět $\mathrm{k}$ poznání reality předškolního vzdělávání v mateřských školách. Současně se mohou stát východiskem pro zaměření dalších výzkumných šetření v této oblasti a podkladem pro další politická rozhodnutí. Studie nabízí výčet témat, která se v uplynulých deseti letech stala předmětem empirických 
šetření zaměřených na předškolní vzdělávání; popisuje cíle, vzorek a metodologii analyzovaných šetření, ale i okruhy problémů, se kterými se praxe i teorie předškolního vzdělávání potýká.

\section{Cíl A METODIKA ANALÝZY}

Předkládaná analýza výzkumů předškolního vzdělávání volně navazuje na analýzu vybraných témat pedagogického výzkumu realizovaných v letech 2000-2010 (Syslová \& Najvarová, 2012). Jde o tzv. literární přehledovou studii (Mareš, 2013, s. 430), jejímž cílem je přinést odpovědi na otázky: (1) Jaká témata a cíle byly ve výzkumech řešeny? (2) Jaké metody byly využívány a na jakých souborech byly studie realizovány? (3) Jaká podstatná zjištění a závěry z těchto studií vyplynuly?

Výzkumné studie byly vyhledávány v odborných časopisech vydávaných v České republice, které jsou sledovány v Bulletinu České asociace pedagogického výzkumu. Jde o časopisy e-Pedagogium, Komenský, Lifelong Learning, Orbis scholae, Pedagogická orientace, Pedagogika, Magister: reflexe primárniho a preprimárního vzděláváni ve výzkumu, Sociologický časopis a Studia paedagogica v letech 2011-2020.

Dalšími zdroji se staly sborníky konferencí České asociace pedagogic- kého výzkumu, České pedagogické společnosti a konference pořádané fakultami garantujícími príípravné vzdělávání učitelů mateřských škol, které vyšly v letech 2011-2020. ${ }^{1}$

Nejprve byly vyhledány studie v časopisech i ve sbornících na základě jejich anotací (abstraktů), které se týkaly problematiky předškolního vzdělávání a dětí předškolního věku. Dále byly studie analyzovány a sestaven soupis empirických studií. Při tomto kroku bylo uplatněno pozitivní kritérium - tj. že empirická studie přináší výzkumné poznatky. Zpravidla obsahuje části, jako jsou teoretická východiska, cíle, metodologie provedeného šetření a jeho základní výsledky. Ty studie, které byly věnovány spíše úvahám nebo měly popisný charakter, byly vyřazeny. Některé z empirických studií se jevily jako problematické, proto jsme príistoupily $\mathrm{k}$ dalšímu posuzování a stanovily jsme si tzv. negativní kritéria pro jejich vyřazení: (a) nejasně formulovaný cíl a chybějící údaje o zkoumaném vzorku a (b) nedostatky $v$ závěrech.

Bylo vyhledáno a následně analyzováno 75 empirických studií.

\section{VÝSLEDKY ANALÝZY}

$\mathrm{V}$ následující kapitole představíme analyzované studie. ${ }^{2}$ Text strukturujeme

\footnotetext{
${ }^{1}$ Jednalo se o sborníky z konferencí Předškolní vzdělávání v pedagogických, psychologických a sociálních souvislostech (Ústí nad Labem, 2011), Hra je krásnou př́pravou k vážným věcem (Hradec Králové, 2014), Předškolní vzdělávání v teorii a praxi (Brno, 2014), Trendy a perspektivy předškolního vzdělávání (Ústí nad Labem, 2016) a Prostor pro preprimární a primární pedagogy (Liberec, 2018).

${ }^{2}$ Odkazy na analyzované studie nalezne čtenář v př́loze přehledové studie.
} 
v souladu $s$ výše uvedenými výzkumnými otázkami. Než přistoupíme $\mathrm{k}$ představení výsledků, rádi bychom uvedli několik statistických zjištění. Nejvíce studií jsme našli v časopise Magister: reflexe primárního a preprimárního vzděláváni ve výzkumu (17) a v časopise e-Pedagogium (14). $\mathrm{V}$ obou prrípadech jde o neimpaktované časopisy. Časopis Pedagogická orientace věnoval v roce 2014 předškolnímu vzdělávání monotematické číslo, celkově v něm bylo uveřejněno sedm studií. Časopis $P e-$ dagogika otiskl rovněž sedm studií. V časopise Orbis scholae jsme našli čtyři studie a v časopise Studia paedagogica tři. Jednu studii jsme vyhledali v časopisech Komenský, Lifelong Learning a v Sociologickém ćasopise. Oproti první přehledové studii vzrostl počet studií ze 42 na 75.

Oproti nárůstu časopiseckých studií můžeme vidět klesající počet studií ve sbornících z konferencí České asociace pedagogického výzkumu (ČAPV) a České pedagogické společnosti (ČPdS). Tento pokles vznikl vydáváním pouhých abstraktů prezentovaných výzkumů (u sborníků ČAPV od roku 2017). Dohledání konferenčních studií také ztížil fakt, že sborníky ČPdS nejsou dostupné v elektronické podobě.

\section{TeMaTiCKÉ ZaMĚŘENí STUdiÍ}

\section{A JEJICH CÍLE}

Zkoumané studie tematicky pokrývají hlavní aktéry předškolního vzdělá- vání, kterými jsou učitelé, ${ }^{3}$ děti a jejich rodiny. Nad rámec hlavních aktérů se studie zaměřovaly také na pregraduální př́ípravu učitelů a na řízení mateřských škol. V tomto ohledu se témata kryjí $s$ tematickým zaměřením výzkumů realizovaných v první dekádě 21. století (Syslová \& Najvarová, 2012).

$\mathrm{K}$ nejpočetnějším patřily studie tematizující učitele mateřských škol, kterých bylo 27 . Zaměřovaly se na různé aspekty vzdělávací práce učitelů, ale také na jejich názory a potřeby. Ty byly sledovány $\mathrm{z}$ nejrůznějších perspektiv. Některé se týkaly potřeb dalšího vzdělávání (Burkovičová, 2017) a obtíží, které učitelé identifikovali u svých profesních činností (Burkovičová, 2012). Část studií se zaměřovala na to, jak učitelé vnímají svoji zdatnost (self-effcacy) pro spolupráci s rodiči (Majerčíková \& Syslová, 2014), jaké jsou jejich názory na sebehodnocení a hodnocení jejich práce (Syslová, 2012) a jak vnímají prestiž svého povolání (Majerč́ková \& Urbaniecová, 2020) či jak vnímají efektivitu preventivních programů v MŠ (Kocourková, Kantorová \& Šafránková, 2014).

Pět studií se věnovalo profesnim dovednostem učitelů. Studie Berčíkové (2016) mapovala využívání tvořivé dramatiky a Semerádová s Hošpesovou (2014) zjištovaly možnosti využití didaktických situací pro rozvoj matematických znalostí. Burkovičová s Kropáčkovou (2014)

\footnotetext{
${ }^{3} \mathrm{~V}$ textu užíváme zpravidla mužský rod, nebot v mateřských školách pracují i muži. Pouze u výzkumů, ve kterých figurovaly ve výzkumném souboru pouze ženy, uvádíme ženský rod.
} 
zkoumaly časové vytížení učitelů v rámci týdenní přímé práce $s$ dětmi. Na využívání konstruktivistických př́stupů byla zaměřena studie Syslové a Ziklové (2016) a direktivitu učitelů řešila ve své studii Feldmanová (2014).

Čtyři studie se věnovaly problematice začinajicích učitelü, zpravidla z pohledu absolventů učitelství, kteří reflektovali své př́pravné vzdělávání (Havel et al., 2018; Syslová \& Parmová, 2017) a kompetence, $v$ nichž se cítili být dobře připraveni na profesi učitele (Soukupová, 2018). Čtvrtá studie se zaměřila na uvádění začínajících učitelů do praxe (Záleská et al., 2019).

Další čtyři studie byly zaměřené na vzdèláváni dètí se speciálnimi vzdèlávacimi potrebami a dètí dvouletých, přičemž Opatřilová (2011) sledovala faktory ovlivňující vzdělávací proces $s$ dětmi $s$ tělesným postižením, Šikulová a Brtnová Čepičková (2011) zjištovaly potřeby učitelů pro práci s dětmi sobtížemi, Šindeláŕová a Drtinová (2016) zaměřily svoji výzkumnou pozornost na jazykovou podporu dětí cizinců a Vašinová se Srbenou (2019) zkoumaly, jak učitelé vnímají vzdělávání dvouletých dětí v současné mateřské škole.

Tři studie se věnovaly diagnostické činnosti učitelì mateřských škol jednak z pohledu materiálů, které učitelé využívají při diagnostice školní zralosti (Kropáčková, 2014) a také z pohledu odkladů povinné školní docházky (Majerčíková, 2017). Třetí studie se zaměřovala na využívání hry jako diagnostického prostředku (Petrová, 2014).
Dvě studie zjištovaly rozdíly v úrovni reflexe (Syslová \& Hornáčková, 2014) a v subjektivním chápání významnosti profesních kompetencí (Smolíková, Bobková \& Kropáčková, 2016) u učitelì materských škol s rüznou úrovni kvalifikace.

Zbývající tři studie jsme zařadili do kategorie rưzné. Jedna $\mathrm{z}$ nich byla zaměřená na zjištování ideálního učitele pohledem dětí (Svobodová \& Novotná, 2017), druhá sledovala rozdíly mezi profesionální kariérou učitelů v mateřské a základní škole (Wiegerová \& Deutscherová, 2018) a třetí přinesla reflexi situace $\mathrm{v}$ mateřských školách v době pandemie (Majerčíková, Horníčková \& Lorencová, 2020).

Druhým nejčastěji tematizovaným aktérem vzdělávání bylo dítě. Dítě se stalo předmětem zkoumání 23 studií. Nejčastěji jsme ve studiích identifikovali zaměreni na dovednosti dètí a jejich zapojováni a aktivitu $v$ rüzných typech činností. Jednalo se zejména o sledování předčtenářské gramotnosti (Cibáková et al., 2019) či s ní spojených dalších dovedností jako je úroveň znalosti konvencí tištěného textu u souboru českých dětí v předškolním věku a faktorů, kterými je tato úroveň podmíněna (Gavora, 2020), z pohledu dovednosti napsat svoje jméno (Viktorová, 2013), z hlediska orální řeči (Mlčáková, 2017) či sledováním sluchových dovedností v běžné populaci a u dětí s odlišným mateřským jazykem (Kmentová, 2016). Jazykové schopnosti byly zkoumány také u dysfatických předškoláků 
(Jagerčíková \& Kucharská, 2012). Dále byl sledován rozvoj předmatematických představ při ověřování elektronické didaktické pomůcky (Čermák, 2017), ale také z pohledu dětí se zrakovým postižením (Kovácsová, Třečková \& Vítová, 2011). Dvě studie byly zaměřeny na rozvoj pohybových dovedností (Miklánková et al., 2016; Miklánková, Sigmund \& Frömel, 2011). Hrbáčková (2011) experimentálně ověřovala pilotní program metakognitivní intervence a jeho vliv na rozvoj myšlení dětí ve věku pět a šest let.

Poměrně často se studie zabývaly školni zralostí děti at už z hlediska možných rozdílů mezi chlapci a dívkami ve vybraných oblastech diagnostiky školní zralosti (Petrová et al., 2013), nebo z hlediska sociálních dovedností a jejich predikční síly pro úspěšnost dětí v 1. ročníku základní školy (Chvál \& Kropáčková, 2017). Sociální dovednosti sledovaly i Šmelová a Berčíková (2016), tentokrát při nástupu dětí do povinného primárního vzdělávání. Využití imaginativní hry pro potřeby pedagogické diagnostiky jako ukazatele školní připravenosti sledovaly Šmelová s Provázkovou Stolinskou (2019). $\mathrm{Na}$ úroveň komunikativních dovedností na konci předškolního vzdělávání byla zaměřena studie Zajitzové (2013).

Tři studie se zabývaly otázkou prekonceptů dětí, dvě s tématem lásky (Provázková Stolinská, 2019a, 2019b) a jedna se zaměřením na lidský trávicí systém (Dalajková \& Trávníčková, 2020).
Zbývající čtyři studie jsme zařadili do kategorie rưzné, nebot se dotýkaly různých aspektů vzdělávání dětí. Havigerová, Haviger a Juklová (2013) porovnávali míru shody v hodnocení dětí mezi učiteli MŠ a rodiči. Havigerová, Smetanová a Křoustková-Moravcová (2016) také sledovaly, zda existuje korelace mezi projevy kreativity a nadáním u dětí předškolního věku. Seidlová Málková (2012) sledovala výkonový profil zaznamenaný při administraci testů u českých dětí předškolního věku ve věku 3,5-5 let. Vacek (2014) zjištoval, zda existují - př́ípadně v jakém počtu - děti, které nejen v úsudku, ale i $\mathrm{v}$ chování mohou být označeny za „dobré“.

$\mathrm{V}$ pořadí třetí, co do četnosti, se staly studie zaměřené na př́pravné vzdělávání učitelů mateřských škol $\mathrm{v}$ počtu 12. Také $\mathrm{v}$ tomto tématu jsme identifikovali několik kategorií. Tou první byla motivace ke studiu. Jaké motivy vedly $\mathrm{k}$ volbě studia, sledovala Wiegerová s Gavorou (2014) a obdobně volila výzkumnou otázku Burkovičová (2015), která zjištovala vnější i vnitřní činitele, které ovlivnily volbu studia. $S$ nástupem do studia souviselo také zjištování potřeb a očekávání studentů vztahujících se $\mathrm{k}$ jejich prrípravě pro učitelskou dráhu (Zormanová, 2011).

Další kategorií bylo sledování profesnich dovedností studentĩ, at již z hlediska vlastního hodnocení jejich profesního rozvoje (Sovová \& Podpera, 2014), tak dílčího sledování jejich zájmu o témata environmentální výchovy (Krou- 
fek, 2016) či chyb spojených s pozorováním vybraných objektů (Frýzová, 2014) a jejich pohledu na matematiku jako vědní obor (Nováková, 2018).

Sledované byly také role, jaké studentky zastávají např. ve hře (Grůzová \& Syslová, 2014), v didaktických situacích (Semerádová \& Hošpesová, 2013), ale i obecně z pohledu profesních dovedností, které je na různé role připravují (Syslová \& Grůzová, 2019).

Do kategorie různé $\mathrm{v}$ rámci třetího tématu jsme zařadili dvě studie zabývající se zaměřením pozornosti studentů (Syslová, 2016b) a vnímáním dítěte a dětství (Wiegerová \& Gavora, 2015).

Čtvrtým tématem byla rodina, na kterou se zaměřovalo šest studií. Vzhledem $\mathrm{k}$ počtu a variabilitě zaměření těchto studií jsme je dále nekategorizovali. Některá témata se však objevovala již výše, např. rozvoj předčtenářské gramotnosti, který byl tentokrát sledován $\mathrm{z}$ hlediska domácího čtení dětem (Gavora, 2016), ale také z pohledu rozvoje komunikačních kompetencí dětí ze sociálně znevýhodněného prostředí (Chudý, Jůvová \& Bazalová, 2018). Rodiny se statusem sociálního znevýhodnění vyhledávala Picková (2017), která chtěla zjistit názory těchto rodičů na výchovu a vzdělávání $\mathrm{v}$ předškolním období a na úlohu předškolního vzdělávání. Také situace zařazování dvouletých dětí do MŠ již byla sledována $\mathrm{z}$ pohledu učitelů $\mathrm{MS}$. $\mathrm{Z}$ pohledu rodičů tuto problematiku sledovala Grůzová se Syslovou (2020). Svobodová a Simonová (2013) sledovaly rozhodo- vání o zahájení povinného vzdělávání a volbě školy a Majerčíková s Rebendovou (2017) zjištovaly, jaký význam připisují vysokoškolsky vzdělaní rodiče předškolnímu vzdělávání.

Posledním tématem, kterému se analyzované studie věnovaly, bylo řízení MŠ. Takto orientované studie jsme našly tři. Bartošová a Hornáčková (2011) sledovaly nabídku nadstandardních aktivit v mateřských školách a zjištovaly jejich organizaci a zajištění. Simonová, Potužníková a Straková (2017) mapovaly názory a postoje ředitelek mateřských škol $\mathrm{k}$ zavedení povinného předškolního vzdělávání, ale také $\mathrm{k}$ dalším otázkám souvisejícím $s$ předškolním vzděláváním. Autorský kolektiv pod vedením Koželuhové (Koželuhová et al., 2020) analyzoval způsoby, jakými je plánován vzdělávací obsah ve vybraných předškolních vzdělávacích programech v České republice a na Slovensku.

\section{VÝZKUMNÉ METODY}

\section{A VÝZKUMNÝ VZOREK}

V analyzovaných studiích byl nejpoužívanější metodou dotazník (14 případů). Ve většině př́ípadů nebylo poskytnuto mnoho informací o vlastnostech použitého nástroje, způsobu jeho distribuce a sběru dat. Při vyhodnocení získaných dat se autoři většinou spokojovali s využitím deskriptivní statistiky a absolutních a relativních četností. Velikost vzorku byla velmi rozmanitá od jednotek respondentů až po téměř tisícovku. 
Druhou nejčastěji používanou metodou byl rozhovor (11 př́padů). Ten byl používán pro zjištování informací od menšího počtu respondentů (od 3 do 58) a téměř vždy byl realizován jako hloubkový. Ve čtyřech př́padech bylo využito ohniskových skupin. Respondenty v těchto rozhovorech byli učitelé, rodiče i děti. Data byla často současně získávána od různých skupin respondentů.

V devíti případech byla hlavní výzkumnou metodou obsahová analýza volných výpovědí respondentů $k$ určitému okruhu problémů/témat. Velikost vzorku se pohybovala v rozmezí od 10 do téměr 180 respondentů.

Pozorování se stalo hlavní výzkumnou metodou osmi výzkumů. Za zajímavé považujeme, že z toho šest výzkumů využilo zprostředkovaného pozorování při analýze videozáznamů.

Další výzkumnou metodou, která byla použita ve větší míře, bylo testování (7 studií). Jednalo se zejména o testy školní zralosti dětí a testování dětí s různými obtížemi či speciálními vzdělávacími potřebami.

Další výzkumné metody se již objevovaly pouze ojediněle. Jednalo se o akční výzkum (2), analýzu dětské kresby (2), záznamy pohybových aktivit dětí (2), experiment (2), metodu konceptuálního mapování, škálování, obsahovou analýzu dokumentů, počítačem řízené testování.

Design provedených výzkumů byl nejčastěji koncipován kvantitativně nebo kvalitativně. Objevily se však i studie, které měly ambici naplnit požadavky smíšeného designu. V nich autoři na základě logického zdůvodnění kombinovali metody kvalitativního i kvantitativního př́stupu. Takových studií jsme identifikovali šest.

\section{ZJIŠTĚNí PLYNOUCÍ Z VÝZKUMŮ}

Zjištění plynoucí z analyzovaných studií jsme organizovali $\mathrm{v}$ souladu $s$ tématy a cíli, které jsme představili výše. Vybrali jsme pouze podstatná zjištění, která př̌inášejí nové či závažné informace využitelné pro koncepční rozhodování o podobě předškolního vzdělávání. Současně jsme si vědomi rizika zkreslení pohledu na předškolní vzdělávání, nebot' většina výzkumů, jak jsme uvedli výše, pracuje s malým výzkumným vzorkem. To je také důvodem, proč mohlo dojít $\mathrm{k}$ některým zjednodušením $\mathrm{v}$ prezentaci výsledků a vzhledem $\mathrm{k}$ omezenému rozsahu časopiseckého př́spěvku také $\mathrm{k}$ menší hloubce analýzy a interpretace nálezů.

Co se týká učitelů mateřských škol, ukazuje se, že středoškolsky vzdělané učitelky projevují nejistotu při hodnocení (sebereflexi) svých profesních dovedností a jejich reflektivní dovednosti vykazují nižší hladiny myšlenkových operací oproti vysokoškolsky vzdělaným učitelkám (Syslová \& Hornáčková, 2014). Rozdíly se ukazují také v kvalitě profesních dovedností mezi učiteli s různou úrovní kvalifikace (Wiegerová et al., 2015). 
Další studie, která sledovala rozdíly v subjektivním chápání významnosti profesních kompetencí u učitelů mateřských škol s různou úrovní kvalifikace, tyto odlišnosti nepotvrdila (Smolíková et al., 2016). Přináší informace o tom, že většina učitelů považovala oblast spolupráce $s$ rodinou a širší veřejností za svou nejméně rozvinutou profesní kompetenci.

To je naopak v rozporu se zjištěními Majerčíkové a Syslové (2014), které ze self-efficacy učitelů mateřských škol vyvozují, že ty disponují silným přesvědčením o svých schopnostech pro spolupráci s rodinou. Zajímavé se pak v tomto světle jeví zjišstění Majerčíkové (2017), která hovoří o tom, že učitelé označují rodiče jako „problém“ při diagnostikování obtíží z hlediska školní zralosti a připravenosti dětí na základní školu, tzn. z hlediska odkladů školní docházky. Podle učitelů jde o pohodlnost, oddalování povinností a prodlužování dětství ze strany rodičů. Hovoří také o „zklamání jménem poradna“, nebot podle učitelů poradny píśí stejné posudky na různé děti a vyhoví rodičům téměř bez výjimky, „důvod pro odklad [poradny] vždycky najdou" (s. 18). S ohledem na školní zralost je vhodné zmínit, že většina učitelů se zabývá diagnostikou školní zralosti a připravenosti a nejčastěji využívá metodiku Pedagogické hodnoceni v pojetí RVP $P V$ (Smolíková et al., 2007; Kropáčková, 2014).

Jako poněkud skeptický se jeví pohled učitelů na prestiž povolání učite- le mateřské školy (Majerčíková \& Urbaniecová, 2020). Postrádají respekt ke svému povolání ze strany jak rodičů, tak i širší veřejnosti. Samy deklarují důležitost svého povolání, považují svoji práci za společensky významnou a pocitují nepřiměřené postavení ve vzdělávacím systému vzhledem $\mathrm{k}$ učitelům na navazujících stupních škol. Wiegerová s Deutscherovou (2018) zjistily, že učitelé MŠ rychleji přecházejí ve svém profesním rozvoji do fáze stagnace, což vysvětlují tím, že svoji profesní kariéru začínají relativně brzy, respektive dříve než učitelé na vyšších stupních škol, kteří získávají kvalifikaci vysokoškolským studiem.

Jako tristní se jeví situace v uvádění začínajících učitelů, přestože se většina absolventů vyjadřuje ve smyslu „dobré připravenosti" na vstup do praxe (Havel et al., 2018; Soukupová, 2018). Záleská et al. (2019, s. 168) v závěru své studie uvádí, že výsledky mají „potenciál k využití také v oblasti vzdělávací politiky, a to např́ḱlad při uvažování o změnách $\mathrm{v}$ podpoře uvádění začínajících učitelů do praxe a tvorbě podpůrných opatření pro začínající učitele“. Nedostatky v prripravenosti na profesi učitele mateřské školy se jeví v dovednostech potřebných pro tzv. společné vzdělávání, tedy vzdělávání dětí se speciálními vzdělávacími potřebami, pro komunikaci s rodiči (Havel et al., 2018) a v dovednostech diagnostických a intervenčních (Soukupová, 2018).

Přestože by se mohlo zdát, že společné vzdělávání, které př̀inesl aktualizovaný 
školský zákon v roce 2016, bude znamenat zvýšené požadavky na další vzdělávání $\mathrm{v}$ této oblasti, výzkum provedený Burkovičovou (2017) tyto předpoklady nepotvrdil. Učitelé pocitovaly větší potřeby spíše ve vzdělávání dětí v posledním povinném roce předškolní docházky, které bylo uzákoněno ve školském zákoně v tomtéž roce (2016). V souvislosti se společným vzděláváním se však objevily problémy s tvorbou individuálních vzdělávacích plánů (Opatřilová, 2011). Jako problematická se jeví také podpora rozvoje dětí cizinců (Šindelářová \& Drtinová, 2016). Dětem s odlišným mateřským jazykem je tato podpora poskytována pouze asi v polovině prŕpadů. Negativní jsou postoje učitelů $\mathrm{k}$ zařazování dvouletých dětí do mateřských škol (Vašinová \& Srbená, 2019) zejména z hlediska naplněnosti tříd a nedostatku pedagogických pracovníků vzhledem k uspokojování potřeb těchto dětí. Studie Petrové (2014, s. 31) se k vysokým počtům dětí ve trrídách mateřských škol vyjadřuje z hlediska diagnostikování a uvádí, že „je-li početnost tříd do 20 dětí, učitel má více prostoru pro provádění pedagogické diagnostiky př̀i hrách. Za zmínku však ještě stojí fakt, že je-li do tř́ídy zařazen větší počet dětí trríletých, či dokonce ještě mladších, je provádění průběžné diagnostiky př́i jakékoli aktivitě velmi obtížné, protože $\mathrm{v}$ takových př́padech učitel plní roli spíše pečovatelskou než profesně odbornou.“

Jako problematické se jeví také vzdělávání dětí v přípravných ročnících základních škol. Šikulová a Brtnová
Čepičková (2011) upozorňují, že zřizování těchto tříd je v rozporu s reformními snahami o zajišstění rovnoprávného př́stupu ke vzdělávání, kdy vytváření pestrých sociálních skupin výrazně pomáhá sociálně znevýhodněným dětem ke zlepšení šancí na školní úspěch.

Studie zaměřené na dítě přinesly informace o ověrování dopadů vzdělávací nabídky na rozvoj dětí, at již šlo o rozvoj předčtenářské gramotnosti při ověřování projektových aktivit realizovaných v mateřských školách (Cibáková et al., 2019) či o vliv pohybových aktivit v mateřských školách na zvýšení aktivního energetického výdeje (Miklánková et al., 2011, 2016). Také experimentálně ověřovaný pilotní program metakognitivní intervence přinesl rozdíly $\mathrm{v}$ pre-testech a post-testech, které vykázaly významnou změnu $\mathrm{v}$ úrovni kognitivního myšlení (Hrbáčková, 2011). Silný vliv školního prostředí na citový rozvoj dítěte spatřila ve svých výzkumech Provázková Stolinská (2019a, 2019b).

Sledováním dětí se speciálními vzdělávacími potřebami zjistila Mlčáková (2017) při vyšetřování porozumění orální řeči, že děti z logopedické třídy dosáhly slabších výsledků než děti z běžných tříd, přestože byly průměrně o 11 měsíců starší. Kmentová (2016) při porovnávání sluchových dovedností mezi běžnou populací a dětmi s odlišným mateřským jazykem zjistila, že dosáhly stejných výsledků. Z hlediska jazykových dovedností se ukázalo, že $58 \%$ dysfatických dětí dosahuje na konci prvního ročníku signifikant- 
ně horších výsledků než běžně se vyvíjející vrstevníci $\mathrm{v}$ úlohách zaměřených na některou z oblastí rozvíjející se gramotnosti (čtení, psaní, čtení s porozuměním; Jagerčíková \& Kucharská, 2012). U dětí se zrakovým postižením a u zdravých dětí jsou výsledky v oblasti matematiky srovnatelné (Kovácsová et al., 2011).

Studie zaměřené na sledování školní zralosti přinesly informace o tom, že existují rozdíly mezi děvčaty a chlapci, kdy lepších výsledků ve většině oblastí dosahují dívky; výjimkou jsou výsledky verbálního myšlení, ve kterém byli úspěšnější chlapci (Petrová et al., 2013). Co se týká sociálních dovedností, v těch dosahují děti z hlediska zralosti uspokojivých výsledků (Šmelová \& Berčíková, 2016) a právě sociální zralost, respektive nezralost, je u rodičů často důvodem $\mathrm{k}$ rozhodnutí o odkladu školní docházky (Chvál \& Kropáčková, 2017). Gavora (2020) přinesl informace o tom, že většina rodin dětem čte několikrát za týden a má dostatečný počet knih, nicméně zjistil téměř nulovou korelaci mezi frekvencí čtení dítěti a znalostmi konvencí textu. To, že děti umí relativně brzy napsat své jméno, ale nerozumí svému zápisu, zjistila Viktorová (2013). Z hlediska konceptualizace jména potom většinou tato dovednost nepředchází významně ostatnímu psaní a čtení. Při posuzování školní př̀ipravenosti $\mathrm{v}$ rámci interpersonálních vztahů zjistila Šmelová s Provázkovou Stolinskou (2019), že má významné místo imaginativní hra. Výzkum Za- jitzové (2013) ukázal, že z hlediska požadavků RVP PV nedosahují děti na konci předškolního vzdělávání dobrých výsledků v oblasti komunikativní kompetence. Maxima ve všech sledovaných dovednostech dosáhlo pouze $6 \%$ dětí z výzkumného souboru.

Havigerová et al. (2013) zjistili, že rodiče i učitelé byli ve shodě při posuzování chování předškolních dětí pomocí škály charakteristik nadání (Characteristic of Giftedness Scale). Také další výzkum Havigerové et al. (2016) ukazuje, že korelace různých typů kreativity je silnější v raném věku, zatímco doménově-specifická kreativita přichází $s$ věkem a zkušenostmi.

Témata př́ípravného vzdělávání učitelů mateřských škol přinesly informace o motivaci studentů zlínského bakalářského studia učitelství v mateřské škole. Polovina participantek zvolila už po základní škole střední pedagogickou školu, čtvrtina participantek měla studium učitelství jako druhou volbu. Wiegerová s Gavorou (2014) také identifikovali, že významnými osobnostními faktory pro volbu povolání učitelek MŠ jsou feminita a emocionalita. Burkovičová (2015) zjištovala motivační faktory u studentů Ostravské univerzity. $\mathrm{K}$ těm vnitřním patřily silné pozitivní city $\mathrm{k}$ dítěti a vliv rodiny. Vliv rodiny naopak vyvrátil výzkum Zormanové (2011). Ta zjištovala spíše očekávání studentů, která nejčastěji směřovala $\mathrm{k}$ potřebě naučit se dobře organizovat činnosti dětí, vhodně s nimi komunikovat. $\mathrm{K}$ dalším motivátorům studentů 
plzeňské fakulty patřila práce $s$ dětmi, ale také výhoda státního místa, prázdniny, seberealizace a naplnění ideálů (Sovová \& Podpera, 2014).

Č́st výzkumů se orientovala na studenty kombinovaného studia, kteři již v mateřských školách pracují. Výzkumy ukázaly, že při pozorování objektů se tyto studentky řídí především svou intuicí, nikoli pravidly efektivního využívání této didaktické metody, mnohé dokonce netuší, že pozorování je jednou z didaktických metod (Frýzová, 2014). Pro realizaci didaktických situací zaměřených na rozvoj matematických představ dětí potřebují tyto zkušenosti zásobu prŕkladů a $\mathrm{v}$ neposlední řadě hlubší znalosti matematického obsahu (Semerádová \& Hošpesová, 2013). K obdobným zjištěním došla také Nováková (2018) u studentek prezenčního studia. Podle ní požadují studentky pro svou profesní výbavu spíše konkrétní náměty, bezprostředně využitelné v praxi mateřské školy. Další prohlubování svých teoretických znalostí základů matematiky v rámci vysokoškolského studia často považují za nepotřebné, neužitečné a na úkor vlastní praxe.

Čtvrté téma věnované rodinám přineslo informace o tom, že zkoumané rodiny organizují večerní čtení jakožto rodinnou rutinu (Gavora, 2016). Jako motiv uváděli rodiče uklidnění dítěte a jeho usnutí. Matky v těchto rodinách četly častěji než otcové. Další výzkum ukázal, že v rodinách ze sociálně znevýhodněného prostředí se dětem nedostává základních aktivit, jako je čtení, zpěv, vyprávění pohádek, hraní společenských her nebo výtvarné činnosti, naopak většinu volného času tráví před televizí (Chudý et al., 2018). Rodinám s tímto statusem se věnovala i Picková (2017), která zjistila, že tyto rodiny mají silný ochranitelský výchovný styl a nechtějí dávat děti do $M S ̌$ z důvodu předčasné scholarizace. Opačný pohled na předškolní vzdělávání přináší výzkum Majerčíkové s Rebendovou (2017), které se zaměřily na vysokoškolsky vzdělané rodiče. $\mathrm{Ti}$ důvěřují učitelům a jejich odborným kompetencím a tomu, že jejich děti připraví na vstup do povinného vzdělávání. Často mají zájem angažovat se ve správě školy. Jeden z výzkumů se zabýval názory rodičů na odklad školní docházky a přinesl velmi různorodá zjištění od odmítnutí možnosti odkladu pro svoje děti až k tzv. prodloužení dětství díky odkladu (Svobodová \& Simonová, 2013). Různorodost názorů rodičů na zařazování mladších než tříletých dětí přinesl výzkum Grůzové se Syslovou (2020). To, co bylo pro většinu rodičů, respektive matek, společné, byla preference postupné adaptace, popř. využití krátkých forem hlídání, kdy převažuje rodičovská péče, přičemž $\mathrm{v}$ případě maladaptačních projevů dítěte rozvolňují docházku a dávají dětem čas. Všichni respondenti byli připraveni dítěti proces adaptace i návštěvu zařízení zpř́íjemnit.

Posledním tématem, kterému se analyzované studie věnovaly, bylo řízení MŠ. První studie odrážely problémy 
přetrvávající z první dekády 21. století, a to $\mathrm{v}$ přemíre nadstandardních aktivit nabízených $\mathrm{v}$ mateřských školách a vedených externími pracovníky. Většina mateřských škol nabízela tyto aktivity z obav, aby neztratila zájem rodičů o jejich MŠ (Bartošová \& Hornáčková, 2011). V roce 2017, kdy byl uzákoněn povinný poslední rok předškolního vzdělávání, odhalil výzkum Simonové, Potužníkové a Strakové (2017), že ředitelky nesouhlasí se zavedením povinného předškolního vzdělávání a vnímají ho pouze jako formální opatření. Třetí studie pak odhalila, že většina školních vzdělávacích programů upřednostnuuje chronologické zpracování integrovaných vzdělávacích bloků, které však nepodporuje uspokojování potřeb a zájmů dětí v souvislosti se situačním a prožitkovým učením (Koželuhová et al., 2020).

\section{DISKUSE A ZÁVĚRY}

$\mathrm{V}$ této studii jsme přinesli ucelený přehled oblastí empirického zkoumání předškolního vzdělávání tak, jak byly publikovány mezi lety 2011 a $2020 \mathrm{v}$ relevantních českých odborných periodicích a sbornících z konferencí. Analýza jednotlivých studií nám umožňuje zhodnotit jejich výsledky po stránce obsahové i metodologické.

Pokud bychom daly výsledky této studie do souvislosti se závěry šetření České školní inspekce (ČŠI, 2020, s. 48), můžeme nalézt doklady toho, že české předškolní vzdělávání se i po 20 letech stále potýká s poměrně velkými problémy v oblasti implementace kurikulární reformy. „V pedagogickém řízení školy chybí důsledná kontrola zavádění metod a forem vedoucích $\mathrm{k}$ individualizaci předškolního vzdělávání a zkvalitnění průběhu vzdělávání. U většiny škol byla tato oblast hodnocena na úrovni vyžadující zlepšení. Školám se dlouhodobě nedaří nastavit efektivní systém zjištování a vyhodnocování vzdělávacích pokroků jednotlivých dětí a následnou realizaci jejich osobnostního rozvoje individualizovanou podporou." $\mathrm{Na}$ tento problém upozornily i další studie (např. Šmelová, Petrová \& Souralová, 2012). Upozorňují také na nefunkční spolupráci MŠ a rodiny při předávání informací o dětech a při společné podpoře rozvoje dítěte (např. Greger et al., 2015, s. 154).

Některá zjištění naznačují, že vyšší kvalifikovanost učitelek vede $\mathrm{k}$ lepší vybavenosti profesními znalostmi než u učitelek s nižší kvalifikovaností, což je $\mathrm{v}$ souladu $s$ kvalifikačními požadavky uvedenými v Národní soustavě povolání České republiky, ve které se uvádí, že „nejvhodnější přípravu pro tuto pozici [pozn. učitele mateřské školy] poskytuje magisterský studijní program v oboru předškolní a mimoškolní pedagogika“. Nelze však nevidět tlaky, které se objevují v souvislosti $s$ neoliberálními principy ve školství a které směřují ke snižování kvalifikačních požadavků obecně (např. Spilková \& Wildová, 2014). Na potřebu vysokoškolského vzdělávání učitelů 
mateřských škol upozorňovala již Bílá kniha (2001) a v neustálých vlnách se tento požadavek vynořuje $\mathrm{v}$ různých studiích u různých autorů (Kropáćková \& Janík, 2014; Syslová, 2017; Syslová et al., 2013; Wiegerová et al., 2015). Jak jsme uváděli výše, pro kvalitní vzdělávání potřebujeme kvalitní a vysoce kvalifikované učitele, nebot́ existují doklady, že existuje souvislost $s$ jeho pozdějšími ekonomickými i sociálními dopady na jedince a celou společnost. Představitelé školské politiky však tomuto tématu nevěnují dostatečnou pozornost.

$Z$ výsledků analýzy vyplynulo, že se nezměnilo tematické zaměření dílčích studií, ale vzrostl počet publikovaných studií v recenzovaných časopisech. Největší nárůst realizovaných studií jsme zaznamenali v oblasti Učitel $\left(10 / 27^{4}\right)$ a Dítě (9/23), obdobný počet studií byl proveden v oblasti Pregraduální vzdělávání učitelů MŠ (10/12) a Rodiny (7/6). Pokles $\mathrm{v}$ počtu provedených studií je patrný v oblasti Ŕízení MŠ (6/3). Mezi realizovanými studiemi jsme identifikovali čtyři přehledové studie, které $\mathrm{v}$ předchozím sledovaném období nebyly realizované vůbec (Kropáčková, Wildová \& Kucharská, 2014; Syslová, 2016a; Syslová \& Najvarová, 2012; Včelařová et al., 2014).

Z tohoto faktu bychom mohli usoudit na zvyšující se kvalitu výzkumu v oblasti předškolního vzdělávání. $Z$ metodologického hlediska došlo $\mathrm{k}$ posunu od čistě kvantitativně orientovaného výzkumu $\mathrm{k}$ výzkumným šetřením zaměřeným kvalitativně, $\mathrm{v}$ některých př́ípadech až $\mathrm{k}$ designu smíšenému. Posun jsme zaznamenali $\mathrm{v}$ použitých metodách - od použití dotazníků (v minulosti značně problematických) k realizaci (hloubkových) rozhovorů, videostudiím a vybraným metodám typickým pro kvalitativní př́stup zkoumání. U některých studií se stále objevují metodologické nedostatky a problémy. Za nejpodstatnější považujeme $\mathrm{v}$ některých případech nedostatečně popsanou fázi sběru dat a u kvantitativně orientovaných studií chybějící údaje o vlastnostech použitých nástrojů.

$\mathrm{Z}$ analyzovaných studií ale stále přetrvává pocit roztř́šstěnosti výzkumného zaměření. Zdá se, že v oblasti výzkumu předškolního vzdělávání chybí významné téma, které by rezonovalo celou komunitou. Předmětem výzkumů tak často byla $\mathrm{v}$ obou sledovaných obdobích dílčí drobná specifika, která neumožňují zobecnění výsledků na širší populaci, ale vlastně ani nepřispívají do znalostní základny oboru.

Roztř̌ršstěnost výzkumných témat a zpravidla malý výzkumný vzorek nepřináší validní informace o efektech českého předškolního vzdělávání, a poskytuje tak jen malé vodítko pro jeho další rozvoj. „Nejsou dosud k dispozici robustní empirická data, ze kterých by mohla vycházet politika př̀edškolního

${ }^{4}$ Počet studií v období do roku 2010 / počet studií ve sledovaném období. 
vzdělávání a péče v České republice“ (Greger et al., 2015, s. 156). Výše jsme již uváděli, že pro kvalitní politická rozhodnutí jsou potřeba investice do výzkumů, které jsou v České republice evidentně nedostačující.

Směrem ke vzdělávací politice rezonují výsledky několika doporučení. Jedním z nich je zvýšení investic do výzkumu předškolního vzdělávání, aby bylo možné analyzovat a určovat důležité indikátory jeho efektivnosti a přijímat relevantní opatření $\mathrm{k}$ jeho zkvalitňování. Nedostatečně kvalitní předškolní vzdělávání může př́inést dalekosáhlé následky. Slovy Stanislava Vrány (1946, s. 41) „pokazí-li něco učitel u žáka desetiletého, dvanáctiletého, lze to ještě napravit. Ale počíná-li si nemoudře vychovatelka dítěte ve věku předškolním, nikdo nikdy již nenapraví chyby, jichž se dopustila“. Dalším doporučením je dořešit již několik roků otevřené téma trojkolejnosti prrípravného vzdělávání učitelů mateřských škol. ${ }^{5}$ Jedna z možností je uzákonit povinnost vysokoškolského vzdělání učitelů mateřských škol, jako to udělala většina vyspělých zemí světa (European Com- mission, 2019). Další možností je alespoň diferencovat finanční hodnocení učitelů s různou úrovní kvalifikace přijetím nových funkčních míst pro vysokoškolsky vzdělané učitele, jakými jsou např. tř́ídní učitel či výchovný poradce. Nastává nejvyšší čas, aby se představitelé školské politiky začali důsledně zabývat nejen deklarovaným plánováním zkvalitňování předškolního vzdělávání, ale především jeho monitorováním, aby získali pro své plány relevantní informace.

Kromě vzdělávací politiky směřují výsledky také $\mathrm{k}$ akademickým pracovištím zajištujícím př́ípravné vzdělávání učitelů mateřských škol. Bylo by vhodné provádět koordinovanější výzkumy např́ič akademickými pracovišti. Zajímavým tématem $\mathrm{k}$ rozvoji oboru předškolní pedagogika by mohl být přehled českých výzkumů publikovaných v zahraničních časopisech a sbornících z konferencí.

Všechna výše uvedená doporučení by mohla pomoci ke zkvalitnění praxe předškolního vzdělávání, ale současně také $\mathrm{k}$ budování poznatkové báze oboru předškolní pedagogika.

\section{LITERATURA}

Barnett, W. S. (2008). Preschool education and its lasting effects: Research and policy implications.

New Brunswick, NJ: Rutgers University.

European Commission/EACEA/Eurydice. (2019). Key data on early childhood education and care in Europe - 2019 edition. Eurydice Report. Luxembourg: Publications Office of the European Union.

\footnotetext{
${ }^{5}$ Otázka kvalifikace učitelů byla otevřena 12. 1. 2016 na Národním kulatém stole k problematice odborné kvalifikace učitelek mateřských škol na MŠMT.
} 
Greger, D., Simonová, J., \& Straková, J. (Eds.). (2015). Spravedlivý start? Nerovné šance v predškolnim vzdèláváni a při prechodu na základni školu. Praha: Pedagogická fakulta UK.

Heckman, J. J. (2006). Skill formation and the economics of investing in disadvantaged children. Science, 312(5782), 1900-1902.

Heckman, J. J. (2011). The economics of inequality: The value of early childhood education. American Educator, 35(1), 31-35.

Kropáčková, J., \& Janík, T. (2014). Předškolní pedagogika - etablování oboru. Pedagogická orientace, 24(4), 465-467.

Mareš, J. (2013). Přehledové studie: jejich typologie, funkce a způsob vytváření. Pedagogická orientace, 23(4), 427-454.

McClelland, M. M., Acock, A. C., \& Morrison, F. J. (2006). The impact of kindergarten learning related skills on academic trajectories at the end of elementary school. Early Childhood Research Quarterly, 21, 471-490.

MŠMT. (2001). Národní program rozvoje vzdělávání v České republice (Bílá kniha). Praha: MŠMT.

MŠMT. (2004). Rámcový vzdělávaci program pro predškolni vzděláváni. Praha: MŠMT.

OECD. (2012). Education at a Glance: OECD Indicators. Paris: OECD.

Sammons, P., Sylva, K., Melhuish, E. et al. (2007). The Effective Preschool and Primary Education 3-11 project (EPPE 3-11): Influences on children's development and progress in key stage 2: Social/behavioural outcomes in year 5. London: IoEL.

Smolíková, K. (Ed.) (2007). Pedagogické hodnoceni v pojetí RVP PV. Praha: VÚP.

Spilková, V., \& Wildová, R. (2014). Potřebujeme kvalitní nebo kvalifikované učitele? Pedagogická orientace, 24(3), 423-432.

Straková, J., Greger, D., Kalous, J. et al. (2009). Analýza naplněni cílù Národniho programu rozvoje vzdèláváni $v$ České republice (Bílé knihy) v oblasti predškolního, základniho a středního vzděláváni. (Online). Dostupné z www.msmt.cz

Sylva, K., Melhuish, E., Sammons, P., Suraj-Blatchford, I., \& Taggart, B. (2004). The Effective Provision of Preschool Education (EPPE) project: Final report. Nothingham: DfES Publications.

Syslová, Z. (2017). Učitel v predéškolnim vzděláváni a jeho príprava na profesi. Brno: Pedagogická fakulta MU.

Syslová, Z., Borkovcová, I., \& Průcha, J. (2014). Péče a vzděláváni dětí v raném věku. Praha: Wolters Kluwer.

Syslová, Z., \& Najvarová, V. (2012). Předškolní vzdělávání v České republice pohledem pedagogického výzkumu. Pedagogická orientace, 22(4), 490-515.

Šmelová, E., Petrová, A., \& Souralová, E. (2012). Pripravenost dèti k zahájeni povinné školni docházky v kontextu soućasného kurikula. Olomouc: Univerzita Palackého.

Vrána, S. (1946). Česká mateřská škola do nového údobí. Brno: Ústřední učitelské nakladatelství a knihkupectví. 
Wiegerová, A. (Eds.). (2015). Profesionalizace učitelì mateřských škol z pohledu reformy kurikula. Zlín: Fakulta humanitních studií UTB.

Yoshikawa, H., Weiland, C., Brooks-Gunn, J. et al. (2013). Investing in our future: The evidence base on preschool education. Washington: Society for Research in Child Development.

Př́ĺloha I - Seznam analyzovanÝCH Zdrojů

Bartošová, I., \& Hornáčková, V. (2011). Aktuální problémy současné předškolní výchovy. In R. Kroufek \& J. Šlégl (Eds.), Předškolni vzděláváni v pedagogických, psychologických a sociálnich souvislostech (s. 35-41). Ústí nad Labem: Pedagogická fakulta ÚJEP.

Berč́ková, A. (2016). Tvořivá dramatika jako možný prostředek individualizace ve výchově a vzdělávání dětí předškolního věku. In V. Chytrý \& J. Janovec (Eds.), Trendy a perspektivy predškolního vzděláváni (s. 6-14). Ústí nad Labem: ÚJEP.

Burkovičová, R. (2012). Analyzování jako součást diagnostické činnosti učitele v MŠ. In V. Ježková (Ed.), Kvalita ve vzdělávání (s. 128-135). Praha: Pedagogická fakulta UK.

Burkovičová, R. (2015). Věcní a vnitřní činitelé směrování k učitelství pro mateřské školy. Magister, 3(2), 56-73.

Burkovičová, R. (2017). Uspokojování individuálně identifikovaných vzdělávacích potřeb učitelek mateřských škol. Magister, 5(2), 7-22.

Burkovičová, R., \& Kropáčková, J. (2014). Profesní činnosti učitelek mateřských škol ve světle současných českých výzkumů. Pedagogická orientace, 24(4), 562-582.

Cibáková, D., Polák, M., Zatloukalová, M., Oralová, A., \& Holcová, D. (2019). Podpora zájmu dětí Mateřské školy o psanou formu jazyka. Magister, 7(2), 11-31.

Čermák, K. (2017). Elektronická platforma pro vývoj didaktických pomůcek: Pomůcka pro rozvoj předmatematických představ. e-Pedagogium, 17(3), 100-110.

ČŠI. (2020). Kvalita a efektivita vzděláváni a vzdělávaci soustavy ve školním roce 2018/2020 - výročni zpráva ČŠI. Praha: ČŠI.

Dalajková, A., \& Trávnícková, P. (2020). Dětské prekoncepty o fungování lidského těla. e-Pedagogium, 20(2), 59-69.

Feldmanová, A. (2014). Styl vyučování učitele v mateřské škole. Magister, 2(1), 75-115.

Frýzová, I., (2014). Využití didaktické metody pozorování v předškolním vzdělání. In Z. Syslová \& V. Rodová (Eds.), Predškolní vzdéláváni v teorii a praxi (s. 116-123). Brno: Masarykova univerzita.

Gavora, P. (2016). Preschool children in book-reading situations with parents: The perspective of personal agency theory. Studia paedagogica, 21(4), 99-116.

Gavora, P. (2020). Cesta ke čtenářské gramotnosti: Znalost konvencí tištěného textu u dětí předškolního věku. Pedagogika, 70(2), 157-178.

Grůzová, L., \& Syslová, Z. (2014). Př́prava studentek na roli herního partnera. In V. Hornáčková (Ed.), Hra je krásnou prípravou k vážným věcem (s. 282-292). Hradec Králové: Gaudeamus. 
Grůzová, L., \& Syslová, Z. (2020). Childcare for children under three years of age from the mothers' point of view within the international context. Pedagogika, 70(4), 533-552.

Havel, J., Grůzová, L., Najvar, P. et al. (2018). Stávání se učitelem pohledem absolventů učitelství pro MŠ a pro1. stupeň ZŠ. In Z. Pechová, Z. Prokeš, V. Valkoun, \& V. Vykoukalová (Eds.), Prostor pro primárni a preprimární pedagogy (s. 27-36). Technická univerzita Liberec.

Havigerová, J. M., Haviger, J., \& Juklová, K. (2013). Škála charakteristik nadání pro předškolní děti - shody a rozpory v posuzování nadání př̌edškoláků mezi učitelkami MŠ a rodiči. e-Pedagogium, 13(3), 68-80.

Havigerová, J. M., Smetanová, V., \& Křoustková-Moravcová, I. (2016). Talent and creativity in preschool age children: A pilot study. Studia paedagogica, 21(4), 77-98.

Hrbáčková, K. (2011). Vliv metakognitivní intervence na rozvoj myšlení dětí předškolního věku. e-Pedagogium, 11(3), 49-63.

Chvál, M., \& Kropáčková, J. (2017). Sociální dovednosti předškolních dětí a jejich vliv na odklad povinné školní docházky a dosahovaný školní úspěch na konci 1. ročníku základní školy. Orbis scholae, 11(1), 93-117.

Chudý, Š., Jůvová, A., \& Bazalová, S. (2018). Narušená komunikační schopnost dítěte ze sociálně znevýhodněného prostředí jako interdisciplinární problém. Možnosti sociálně pedagogických intervencí. e-Pedagogium, 18(3), 21-35.

Jagerčíková, Z., \& Kucharská, A. (2012). Počátky gramotnosti u česky mluvících dětí s vývojovou dysfázií ve srovnání s běžně se vyvíjejícími vrstevníky. Pedagogika, 61(1-2), $150-163$.

Kmentová, M. (2016). Témbrový a fonematický sluch předškolních dětís atypickým vývojem řeči. e-Pedagogium, 16(1), 51-64.

Kocourková, V, Kantorová, J., \& Šafránková, A. (2014). Evaluation of primary prevention of risk behavior in preschool education institutions from the perspective of teachers. e-Pedagogium, 14(4), 25-37.

Kovácsová, A., Třečková, E., \& Vítová, J. (2011). Level of pre-mathematical imaginations of children with visual impairment of pre-school age. e-Pedagogium, 11(4), 50-61.

Koželuhová, E., Stralczynská Loudová, B., \& Lipnická, M. (2020). Planning educational content in school curriculum documents: Examples of current practice from pre-schools in the Czech Republic and Slovakia. Pedagogika, 70(4), 425-448.

Kropáčková, J. (2014). Školní připravenost dětí pro vstup do základní školy (pedagogická diagnostika a následná intervence v MŠ). In Z. Syslová, \& V. Rodová (Eds.), Předškolní vzdéláváni v teorii a praxi (s. 252-258). Brno: Masarykova univerzita.

Kropáčková, J., Wildová, R., \& Kucharská, A. (2014). Pojetí a rozvoj čtenářské pregramotnosti v předškolním období. Pedagogická orientace, 24(4), 488-509.

Kroufek, R. (2016). Environmentální výzkumná témata v závěrečných pracích studentů učitelství pro mateřské školy na PF UJEP - trendy, překážky, výsledky. In V. Chytrý \& 
J. Janovec (Eds.), Trendy a perspektivy predškolniho vzděláváni (s. 52-57). Ústí nad Labem: Univerzita J. E. Purkyně.

Majerčíková, J. (2017). Odklady povinné školní docházky v perspektivě učitelek mateřských škol. Orbis scholae, 11(1), 9-30.

Majerč́ková, J., Horníčková, B., \& Lorencová, S. (2020). Mateřská škola jako „zabalená krabička“: Sonda do předškolního vzdělávání v čase první vlny pandemie covid-19. Pedagogická orientace, 30(2), 149-171.

Majerčíková, J., \& Rebendová, A. (2017). Edukace v mateřské škole v perspektivě rodičů vysokoškoláků. e-Pedagogium, 17(3), 65-77.

Majerč́́ková, J., \& Syslová, Z. (2014). Profesní zdatnost učitelek pro spolupráci s rodiči: situace v českých a slovenských mateřských školách. In Z. Syslová \& V. Rodová (Eds.), Předškolni vzděláváni v teorii a praxi (s. 124-135). Brno: Masarykova univerzita.

Majerč́íková, J., \& Urbaniecová, K. (2020). Prestiž učitelství v mateřské škole optikou subjektivní percepce učitelek. Studia paedagogica, 25(1), 51-77.

Miklánková, L., Elfmark, M., Sigmund, E., \& Górny, M. (2016). Preprimární vzdělávání versus úroveň pohybové aktivity dětí. Magister, 4(2), 77-91.

Miklánková, L, Sigmund, E., \& Frömel, K. (2011). Dítě v předškolním věku a jeho pohybový režim. e-Pedagogium, 11(1), 78-88.

Mlčáková, R. (2017). Specifika v porozumění orální řeči u dětí předškolního věku mateřské školy logopedické a mateřské školy běžného typu. e-Pedagogium, 17(1), 117-129.

Nováková, E. (2018). Jak vnímají matematiku budoucí učitelé mateřské školy. Magister, 6(2), $7-23$.

Opatřilová, D. (2011). Komparace vybraných indikátorů inkluzívního vzdělávání dětí a žáků $s$ tělesným postižením v běžné mateřské a základní škole. Komenský, 135(3), 11-22.

Petrová, J. (2014). Hra jako prostředek pedagogické diagnostiky. Magister, 2(2), 23-33.

Petrová, A., Plevová, I., Křeménková, L., Dařílek, P., \& Pugnerová, M. (2013). Školní zralost a připravenost v kontextu pohlavních rozdíli̊. Magister, 1(2), 23-42.

Picková, H. (2017). Proč moje děti nechodí do mateřské školy. Př́stup rodičů, jejichž rozhodování neomezuje socioekonomické znevýhodnění. Orbis scholae, 11(1), 51-69.

Provázková Stolinská, D. (2019a). Internalizace v mateřské škole. Magister, 7(1), 55-63.

Provázková Stolinská, D. (2019b). Láska a kamarádství v pojetí dětí v mateřské škole. Magister, $4(2), 55-47$.

Semerádová, S., \& Hošpesová, A. (2013). Didaktické situace v předškolním období. Magister, 1(1), 33-49.

Semerádová, S., \& Hošpesová, A. (2014). Didaktické situace v předškolním matematickém vzdělání. In Z. Syslová \& V. Rodová (Eds.), Předškolní vzděláváni v teorii a praxi (s. 70-80). Brno: Masarykova univerzita.

Seidlová Málková, G. (2012). Vývoj a diagnostika slabičného povědomí v předškolním věku. Pedagogika, 62(1-2), 97-110. 
Simonová, J., Potužníková, E., \& Straková, J. (2017). Poslání a aktuální problémy předškolního vzdělávání - postoje a názory ředitelek mateřských škol. Orbis scholae, 11(1), 71-91.

Smolíková, A., Bobková, P., \& Kropáčková, J. (2016). Profesní kompetence učitelů mateřských škol. e-Pedagogium, 16(3), 53-64.

Sovová, P., \& Podpera, M. (2014). Pohled jednoho ročníku studentů oboru Učitelství pro MŠ jako podklad pro reflexi studia oboru na FPE ZČU. In O. Dymokurský \& T. Kasper (Eds.), Vybrané praktické aspekty kurikulárni reformy v českém vzdělávání (s. 9-23). Brno: Česká pedagogická společnost.

Soukupová, P. (2018). Diagnostická kompetence začínajících učitelů - možnosti pregraduální př́ípravy učitelů versus potřeby současné praxe. In Z. Pechová, Z. Prokeš, V. Valkoun \& V. Vykoukalová (Eds.), Prostor pro primárni a preprimárni pedagogy (s. 123-128). Technická univerzita Liberec.

Svobodová, E., \& Novotná, N. (2017). Ideální učitel/ka v mateřské škole očima dětí. In M. Procházka, M. Rybičková, M. Vítečková \& I. Žlábková (Eds.). Škola a její lidé na křižovatkách (s. 173-183). Brno: Česká pedagogická společnost.

Svobodová, Z., \& Simonová, J. (2013). Přechod mezi preprimárním a primárním vzděláváním - koncepce projektu. In J. Círus (Ed.), Efektivita vzděláváni v promènách společnosti (s. 448-455). Ústí nad Labem: Univerzita J. E. Purkyně.

Syslová, Z. (2012). Modifikace evaluačního nástroje pro hodnocení kvality učitele mateřské školy. In V. Ježková (Ed.), Kvalita ve vzdělávání (s. 194-201). Praha: Pedagogická fakulta UK.

Syslová, Z. (2016a). Kvalita versus kvalifikace: jaké by mělo být př́ípravné vzdělávání učitelů mateřských škol? In V. Chytrý \& J. Janovec (Eds.), Trendy a perspektivy préedškolního vzděláváni (s. 83-94). Ústí nad Labem: Univerzita J. E. Purkyně.

Syslová, Z. (2016b). Rozvoj profesního vidění studentů oboru Učitelství pro mateřské školy. Pedagogika, 66(4), 440-454.

Syslová, Z., \& Grůzová, L. (2019). Jak se promítá diverzita rolí učitele mateřské školy do prŕípravného vzdělávání. In A. Jůvová \& T. Čech (Eds.), Škola pro všechny aneb Interdisciplinarita ve školni edukaci a pedagogických védách (s. 99-116). Brno: Česká pedagogická společnost.

Syslová, Z., \& Hornáčková, V. (2014). Kvalita reflexe v profesním myšlení učitelek mateřských škol. Pedagogická orientace, 24(4), 535-561.

Syslová, Z., \& Parmová, L. (2017). Zkušenosti absolventů oboru Učitelství pro mateřské školy aneb „Na co mě vysoká škola (ne)připravila“. Magister, 5(1), 7-28.

Syslová, Z., \& Ziklová, N. (2016). Developing professional skills in pre-primary teachers via reflexion and self-reflection. e-Pedagogium, 16(2), 108-119.

Šikulová, R., \& Brtnová Čepičková, I. (2011). Přípravná třída jako forma pedagogické intervence pro děti s odlišnými vzdělávacími potřebami. In R. Kroufek \& J. Šlégl (Eds.), Předškolni vzdèláváni v pedagogických, psychologických a sociálních souvislostech (s. 51-77). Ústí nad Labem: Univerzita J. E. Purkyně. 
Šindelářová, J., \& Drtinová, H. (2016). Problematika začleňování dětí-cizinců do českých mateřských škol v Ústeckém kraji. In V. Chytrý \& J. Janovec (Eds.), Trendy a perspektivy předškolního vzdělávání (s. 68-75). Ústí nad Labem: Univerzita J. E. Purkyně.

Šmelová, E., \& Berčíková, A. (2016). Sociálně komunikační dovednosti dětí předškolního věku v kontextu individualizace předškolního vzdělávání. Magister, 4(1), 7-20.

Šmelová, E., \& Provázková Stolinská, D. (2019). Hra jako ukazatel sociálních dovedností dětí předškolního věku v kontextu pedagogické diagnostiky. Magister, 7(1), 9-27.

Vacek, P. (2014). Talent k dobru aneb „Aktivně dobré díté“. In V. Hornáčková (Ed.), Hra je krásnou prípravou k vážným věcem (s. 2-6). Hradec Králové: Gaudeamus.

Vašinová, K., \& Srbená, A. (2019). Pohled učitelek mateřských škol ve městě Olomouci na zařazení dvouletých dětí do mateřských škol. Magister, 7(2), 51-83.

Včelařová, H., Chráska, M., Martincová, J., \& Andrysová, P. (2014). Psychosociální aspekty nadváhy a obezity dětí raného a předškolního věku v kontextu vybraných sociodemografických ukazatelů v ČR a v některých dalších zemích. Sociální pedagogika, 2(2), 9-21.

Viktorová, I. (2013). Psaní vlastního jména v předškolním věku. Magister, 1(2), 67-99.

Wiegerová, A., \& Deutscherová, B. (2018). Srovnání profesní kariéry učitelů dětí předškolního věku a učitelů na základních školách: kvalitativní výzkumné šetření. e-Pedagogium, 18(4), $16-26$.

Wiegerová, A., \& Gavora, P. (2014). Proč se chci stát učitelkou v mateřské škole? Pohled kvalitativního výzkumu. Pedagogická orientace, 24(4), 510-534).

Wiegerová, A., \& Gavora, P. (2015). Conceptualisation of the child and childhood by future pre-school teachers. Pedagogika, 65(5), 502-515.

Zajitzová, E. (2013). Úroveň kompetencí dětí předškolního věku v oblasti jazyka a řeči v kontextu předškolního kurikula. Magister, 1(2), 53-66.

Záleská, K., Juhaňák, L., Trnková, K., \& Šmahelová, M. (2019). Uvádění začínajících učitelů v mateřských, základních a středních školách pohledem jeho hlavních aktérů. Pedagogická orientace, 29(2), 149-171.

Zormanová, L. (2011). Attitude of students studying to be nursery school teachers towards study and their future profession. Lifelong Learning, 1(2), 39-45.

doc. PhDr. Zora Syslová, Ph.D.

Masarykova univerzita, Pedagogická fakulta;

e-mail: syslova@ped.muni.cz

Mgr. Veronika Najvarová, Ph.D.

Masarykova univerzita, Pedagogická fakulta;

e-mail:najvarova@ped.muni.cz 


\section{SYSLOVÁ, Z., NAJVAROVÁ, V. A Review of Research on Preschool Education in the Czech Republic between 2011 and 2020}

The study provides an overview of topics and empirical findings from research conducted in the field of preschool education in the Czech Republic in 2011-2020. It follows up an overview study of research on preschool education in the years 2000-2010. The study analysed research studies that were published in professional journals and relevant proceedings in the period under review. The study answers the research questions: (1) What topics were addressed in the research and what goals were pursued? (2) What methods were used and on what samples were the studies performed? (3) What significant findings and conclusions emerged from these studies? On the basis of their analysis of these studies, the authors came to the conclusion that during the period under review, the emphasis on publishing was shifted to professional journals; however, there was no significant change in the area of topics covered. In the area of research methodology, it is possible to observe a shift to a qualitative or mixed methodology.

Keywords: pre-primary education, review paper, educational research 